\title{
DETEKSI DINI KRISIS LEWAT PROFIT AND LOSS SHARING (PLS)
}

\author{
Khairul Umam Khudhori, Loni Hendri \\ IAIN Curup, UIN Sunan Kalijaga Yogyakarta \\ Email: khairulumamkhudhori@gmail.com, lonihendri.ge@gmail.com
}

\begin{abstract}
Financial crisis is a danger that always haunts financial stability of every country. Islamic finance as the new comer also gets into this trouble. Fortunately, Islamic finance system is stronger than conventional facing the crisis. This strong may come from its principles that support it. This paper uses a library research to examine the PLS system and it benefits to financial stability. The finds of this paper are Islamic financial system is more stable than conventional one, and PLS system can be used as the early warning of financial crisis.
\end{abstract}

Keywords: Financial Stability, Islamic Finance, PLS System

\begin{abstract}
Abstrak: Krisis keuangan merupakan bahaya yang selalu menghantui stabilitas keuangan di setiap Negara. Tanpa terkecuali keuangan Islam sebagai pendatang baru. Untungnya, sistem keuangan Islam lebih kuat dari pada sistem konvensional. Hal ini dikarenakan prinsip-prinsip dalam sistem keuangan Islam itu sendiri yang dapat menopangnya. Tulisan ini menggunakan penelitian pustaka untuk melihat sistem PLS dan manfaatnya bagi stabilitas keuangan. Hasil dari tulisan ini yaitu Sistem keuangan Islam lebih stabil daripada sistem konvensional, dan Sistem PLS dapat digunakan sebagai peringatan awal krisis keuangan.
\end{abstract}

Keyword: Stabilitas Keuangan, Keuangan Islam, Sistem PLS

\section{A. PENDAhuluaN}

Stabilitas keuangan bukanlah sesuatu yang baru dan asing bagi banyak orang. Berbicara stabilitas keuangan, seseorang tidak hanya akan membahas tentang institusi keuangan dan sistem yang berjalan di dalamnya, tapi lebih lanjut akan membahas tentang pertumbuhan ekonomi dan kesejahteraan masyarakat. ${ }^{1}$ Sistem keuangan yang tidak stabil merupakan persoalan berat yang dihadapi semua bangsa. Sejak tahun 1970 hingga 1998 terjadi setidaknya 20 kali krisis keuangan internasional yang menyebabkan setiap negara menderita kerugian Produk Nasional Bruto (PDB) sebesar 15\%.

Puncak krisis keuangan tahun 1997-1998 memunculkan ide untuk meningkatkan pengawasan sektor keuangan di bawah naungan IMF, Bank Dunia dan institusi lainnya dengan menggunakan indikator makroprudensial sebagai indikator kesehatan dan stabilitas sistem keuangan setiap negara. Ide peningkatan pengawasan sektor keuangan ini kemudian berlanjut dengan dibentuknya kelompok atau komite pengawasan stabilitas keuangan seperti Financial Stability Forum (FSF) dan Committee on the Global Financial System (CGFS). ${ }^{3}$

Krisis dunia selanjutnya yang dipandang sebagai krisis paling berat yang

\footnotetext{
${ }^{1}$ Iqbal, dan Mirakhor, An Introduction to Islamic Finance: Theory and Practice, (Singapura: John Wiley and Sons, 2011), hlm. 22

${ }^{2}$ Moorhouse.A, An Introduction to Financial Soundness Indicators, (London: Monetary and Financial Statistics Bank Of England, 2004), hlm. 2

${ }^{3}$ Moorhouse.A, An Introduction ..., hlm. 2
} 
mengguncang sistem keuangan kapitalis adalah krisis keuangan tahun 2008. Pada tahun tersebut, motif keuntungan yang begitu besar mendorong perkembangan struktur keuangan dan produk-produk baru. Perkembangan ini tidak disertai dengan penguatan dan manajemen risiko yang tepat pada setiap tingkatan sehingga memunculkan krisis hebat. ${ }^{4}$

Penyebab krisis keuangan global tersebut dapat di diagnosa melalui empat praktek yang dilakukan dalam perspektif keuangan Islam, yaitu: penciptaaan bunga, menjual utang-subprime mortgage, short selling, dan tidak adanya porsi yang adil dalam pembagian risiko. ${ }^{5}$ Oleh karenanya, diperlukan upaya alternatif untuk mencegah keruntuhan keuangan di masa depan terutama dalam sistem perbankan. Sistem keuangan yang memiliki pengontrolan yang tepat dengan mengedepankan pertumbuhan ekonomi riil adalah sistem keuangan Islam.

Sistem keuangan Islam cenderung menghindari investasi spekulatif seperti derivatif $f^{6}$ yang menyebabkan krisis keuangan yang bersumber dari bank konvensional. Meskipun industri keuangan Islam masih dianggap sebagian orang kurang berisiko karena transaksi keuangan didukung oleh aset fisik. Sistem keuangan Islam tetap dinilai lebih baik karena menerima dampak yang tidak signifikan dari krisis keuangan global. ${ }^{7}$

Hal ini terbukti dengan banyaknya bank konvensional yang dilaporkan bangkrut saat krisis 2008-2009, sementara tidak satupun bank Islam yang gagal. Daya tahan bank Islam ini disinyalir berasal dari aktivitas bank menggunakan sistem bagi hasil (Profit and Loss Sharing/ PLS) yang tidak berhubungan dengan derivatif dan jual beli hutang. Daya tahan ini dapat berkontribusi terhadap stabilitas keuangan internasional. ${ }^{8}$

Bank konvensional mempunyai informasi yang minim tentang debitur dalam menggunakan dananya. Sedangkan bank Islam cenderung mempunyai informasi yang mendalam mengenai operasional perusahaan yang menjadi kliennya. Hal ini membuat bank konvensional menentukan keuntungan tidak sesuai yang sebenarnya sedangkan kesehatan bank Islam terkait langsung dengan perekonomian secara keseluruhan. ${ }^{9}$

Keuangan Islam tidak semata menghindarkan aktivitas dari riba, legalitas operasional dan produk, tapi juga harusnya berkontribusi terhadap pembangunan ekonomi bangsa dan menciptakan ekonomi yang adil lewat prinsip-prinsip yang diterapkan. ${ }^{10}$ Prinsip yang dimaksud di sini adalah model pembiayaan berbasis ekuitas (PLS) yang mengharuskan adanya

\footnotetext{
${ }^{4}$ Ahmed, "Financial Crisis: Lesson for Islamic Finance", ISRA International Journal of Islamic Finance, Vol.I No.1, 2009, hlm.7

${ }^{5}$ Adel Ahmed, "Global Financial Crisis: an Islamic Finance Perspective", International Journal of Islamic and Middle Eastern Finance and Manajemen, Vol. III No.4, 2010, hlm..308

${ }^{6}$ sebuah kontrak bilateral atau perjanjian penukaran pembayaran yang nilainya diturunkan atau berasal dari produk yang menjadi "acuan pokok" atau juga disebut "produk turunan" (underlying product); daripada memperdagangkan atau menukarkan secara fisik suatu aset, pelaku pasar membuat suatu perjanjian untuk saling mempertukarkan uang, aset atau suatu nilai disuatu masa yang akan datang dengan mengacu pada aset yang menjadi acuan pokok. Derivatif juga sering disebut zero sum game yang artinya apabila saya mendapat keuntungan, maka anda mengeluarkan untuk keuntungan yang saya dapatkan. Secara empiris ditetapkan bahwa untuk kelas investor tertentu ketersediaan derivatif mengundang kegiatan spekulasi. Lihat, Siddiqi, "The Current Financial Crisis and Islamic Economic", IIUM Journal of Economics and Management, Vol. XVI No.2, 2008, hlm. 119

${ }^{7}$ Hussein Elasrag, Global Financial Crisis and Islamic Finance, (Germany:University Library of Munich, 2010), hlm. 44

${ }^{8}$ Hassan Ghassan,dkk., "Financial Stability of Islamic and Conventional Banks in Saudi Arabia: a Time Series Analysis", DSS Empirical Economics and Econometrics Working Papers Series, 2013, hlm. 1

${ }^{9}$ Bilal Khan dan Mohammed Emir A.. "The Value of Islamic Banking in the Current Financial Crisis". Review of banking and Financial Law. Vol. XXIX No. 2, 2009, hlm. 441-446

${ }^{10}$ Dusuki, "The Framework of Maqasid Syariah and Its Implication for Islamic Finance". ISRA Research Paper, 2011, hlm.5
} 
survei dan kontrol aktif untuk setiap pembiayaan. ${ }^{11}$

Prinsip Profit and Loss Sharing (PLS) atau di Indonesia lebih dikenal dengan istilah bagi hasil merupakan prinsip transaksi yang digunakan dalam aktivitas keuangan Islam, yang mana pemilik modal dan juga pengelola berkewajiban untuk berbagi untung yang diperoleh dan juga menanggung kerugian bersama-sama. ${ }^{12}$ PLS ini merupakan sebuah sistem kerjasama yang dilandasi filosofi berbagi risiko, tolong menolong dan keadilan dengan mengasumsikan bahwa setiap usaha yang dilakukan oleh sesorang akan selalu menemui risiko yang setara (untung dan rugi). ${ }^{13}$

Dari penjelasan di atas, maka seyogyanya sistem keuangan Islam akan mampu meminimalkan frekuensi krisis keuangan. Dimana sistem keuangan Islam lebih mengedepankan sebuah prinsip dalam kadiah fiqih yang disebut prinsip "al-kharaj bid al-daman" (setiap usaha muncul bersamaan dengan biaya atau hak mendapatkan hasil disebabkan oleh keharusan menanggung kerugian) dan "al-ghunmu bi al-ghurmi" (keuntungan akan muncul beriringan dengan risiko). Oleh karena itu, sistem PLS dapat dijadikan alarm, atau pendeteksi terhadap ancaman krisis yang membayang-bayangi sistem keuangan dan dapat mengurangi masalah subprime dengan pemberian kredit dengan syarat terjangkau dan ini dapat digunakan sebagai penghematan setelah krisis. ${ }^{14}$

\section{B. METODE PENELITIAN}

Metode yang digunakan untuk menganalisis data dalam penelitian ini adalah deskriptif-analitis. Analisis data dimulai dengan memaparkan stabilitas keuangan, sistem keuangan Islam, kemudian dilanjutkan dengan analisis stabilitas sistem keuangan dengan menerapkan prinsip PLS (profit and loss sharing).

Penelitian ini menggunakan data primer berupa buku, jurnal, koran, koran online dan sumber lain yang membicarakan tentang stabilitas keuangan dan stabilitas sistem keuangan Islam dengan sistem PLS. Peneliti melakukan pengumpulan data melalui studi pustaka yang dilakukan dengan mengkaji buku-buku atau literatur serta jurnal ilmiah untuk memperoleh landasan teoretis yang kuat dan menyeluruh tentang stabilitas keuangan dan stabilitas sistem keuangan Islam. ${ }^{15}$

\section{HASIL DAN PEMBAHASAN}

Sistem keuangan merupakan salah satu unsur yang paling penting dari setiap ekonomi suatu Negara. Karenanya, sistem ekonomi tidak akan berfungsi tanpa adanya peran dari sistem keuangan. ${ }^{16}$ Akan tetapi sistem keuangan tersebut harus berjalan dengan seimbang dan stabil. Stabilitas keuangan merupakan suatu kondisi sistem keuangan yang kuat dan mampu menghadapi berbagai guncangan ekonomi sehingga dapat menjalankan fungsinya sebagai perantara keuangan dengan menjalankan mekanisme ekonomi dengan tepat.

Sistem keuangan yang stabil adalah sistem keuangan yang dapat bertahan

\footnotetext{
${ }^{11}$ Ahmed, "Financial Crisis..., hlm. 11

${ }^{12}$ Kettel, Introduction to Islamic Banking and Finance. (Northampton: Printhaus, 2008), hlm. 8

${ }^{13}$ Syafiq M Hanafi, "Time Value of Money dan Implikasi Ekonomi dalam Ekonomi Islam", EKBISI: Jurnal Ekonomi dan Bisnis Islam, Vol.I No.1, 2006, hlm. 13

${ }^{14}$ Adel Ahmed, "Global Financial..., hlm..312

${ }^{15}$ Wirartha, Metodologi Penelitian Sosial Ekonomi. (Yogyakarta: Andi. 2006), hlm. 152

${ }^{16}$ Rizki Dian Mensari dan Ahmad Dzikra, "Islam dan lembaga keuangan Syariah", Al-Intaj; Jurnal Ekonomi dan Perbankan syariah, Vol.III. No. 1, 2017, hlm. 245
} 
menghadapi momok yang bernama krisis yang hadir karena beragam sebab. Diantara penyebab munculnya krisis keuangan secara internasional adalah:

1. Sistem keuangan berbasis utang yang memberikan kemudahan bagi masyarakat untuk memiliki sesuatu lewat jalan kredit. Kegagalan dalam pengembalian utang tersebut akan menimbulkan beragam persoalan bagi institusi keuangan dan akan berdampak pada aktivitas ekonomi secara keseluruhan. ${ }^{17}$

2. Regulasi dan supervisi yang tidak layak di tengah-tengah negara dengan sistem keuangan liberal dan juga tidak adanya disiplin pasar yang memadai. ${ }^{18}$

3. Spekulasi yang belakangan menjadi bagian tidak terpisahkan dari sistem keuangan. ${ }^{19}$

Inilah kemudian yang membuat para ekonom yakin bahwa sistem keuangan Islam kebal terhadap krisis. Sistem keuangan Islam dengan prinsip-prinsip yang telah disebutkan sebelumnya tidak mengenal persoalan-persoalan utama penyebab krisis di atas. Krisis tahun 2008-2009 membuktikan imunitas keuangan Islam tersebut di mana rata-rata institusi keuangan Islam lebih kuat dibanding konvensional dalam menghadapi krisis global tersebut. ${ }^{20}$

Sistem keuangan Islam merupakan sebuah sistem keuangan yang didasarkan pada aturan ketuhanan. Sistem ini bertitik tolak dari Allah dan menggunakan sarana yang tidak dapat dilepaskan dari syariat, sehingga akan menuntunnya menuju stabilitas yang tidak terbantahkan. ${ }^{21}$ Aturan-aturan ke-Tuhan-an tersebut ditujukan untuk mencapai keadilan sosial dan ekonomi, efisiensi ekonomi dan pertumbuhan ekonomi yang tinggi serta stabil. Salah satu aturan tersebut adalah larangan keras terhadap bunga yang pada dasarnya merusak dan menghancurkan sistem keuangan konvensional. Selain larangan terhadap bunga, keuangan Islam karena sistem berbasis ekuitasnya akan kebal terhadap instabilitas. Perolehan keuntungan lewat spekulasi juga merupakan salah satu praktik yang dilarang dalam keuangan Islam, serta adanya kepastian dan kejelasan dalam transaksi terkait barang, harta, waktu dan tempat penyerahan barang yang dibeli adalah sebuah keharusan. Terakhir dan yang paling utama dalam aturan keuangan Islam adalah aktivitas yang dilakukan didasarkan pada keabsahan kontrak yang tidak membolehkan institusi untuk memberikan pembiayaan pada usaha yang tidak halal. ${ }^{22}$

Sementara itu, Indonesia sebagai negara dengan perekonomian terbuka tentunya tidak akan pernah lepas dari dampak keuangan global, termasuk krisis keuangan. Krisis 2008-2009 merupakan salah satu krisis global yang berdampak terhadap pertumbuhan ekonomi tanah air. Meskipun begitu, sejak tahun 2008 itu pula keuangan Islam di tanah air berkembang pesat.

Bulan-bulan pertama pada tahun 2009 terjadi penambahan jaringan pelayanan bank Islam. Tidak hanya itu, pertumbuhan kinerja pun masih tetap tinggi pada awal tahun 2009 tersebut dan juga penyaluran pembiayaan oleh bank Islam juga ikut mengalami peningkatan. Hal ini lagi-lagi menunjukkan bahwa institusi keuangan Islam merupakan elemen yang

\footnotetext{
${ }^{17}$ Moisseron, J. Y dan Teulon, "Are Moral Islamic Economics an Answer to the Global Financial Crisis?”, IPAG Business School Working Paper, 2014, hlm. 52

${ }^{18}$ Dogarawa, "Global Financial Crisis and the Search fo New Financial Architecture: Can Islamic Finance Provide Alternative?", Journal of Islamic Economics, Banking and Finance, Vol.VIII No.4, 2012, hlm. 36

${ }^{19}$ Moisseron, J. Y., dan Teulon, F, “Are Moral..., hlm.52

${ }^{20}$ Dogarawa, "Global Financial..., hlm. 38

${ }^{21}$ Rina Desiana dan Nonie Afrianty, "Landasan Etika dalam Ekonomi Islam”, Al-Intaj:Jurnal Ekonomi dan Perbankan Islam, Vol.III No. 1. 2017, hlm. 122

${ }^{22}$ Dogarawa, "Global Financial..., hlm. 38
} 
tangguh dalam menyangga stabilitas sistem keuangan nasional dan global.

Ketidakstabilan keuangan (krisis), salah satunya disebabkan oleh kegagalan bank dalam mengelola pinjaman ataupun kerugian dalam perdagangan, sehingga wajar pula jika bank dianggap sebagai level krusial deteksi risiko sistem keuangan. Berdasarkan penelitian yang sudah ada, didapati bahwa perbankan Islam bisa menjadi penopang stabilitas keuangan nasional dan global. Hal ini barangkali dilatarbelakangi oleh prinsip-prinsip keuangan Islam yang diterapkan dalam sistem perbankan Islam. Salah satu prinsip tersebut dan juga merupakan pembeda utama sistem perbankan Islam dari konvensional adalah sitem Profit and Loss Sharing (PLS) atau lebih dikenal di tanah air dengan istilah Bagi Hasil.

Berdasarkan kata-kata yang menyusunnya, kita dapat memahami bahwa dalam sistem PLS, yang dibagi tidak hanya keuntungan, melainkan juga kerugian ditanggung bersama. Sebagaimana dipaparkan pada bagian teori, sistem PLS adalah model pengganti bunga yang tidak dibenarkan dalam sistem keuangan Islam. Sistem ini tidak hanya diterapkan dalam aktivitas perbankan, namun dapat juga diaplikasikan pada aktivitas keuangan lainnya. Sistem ini memiliki keunggulan dibandingkan sistem bunga jika dipahami secara menyeluruh oleh masyarakat dan lembaga keuangan.

Pada sistem PLS, pemilik modal dan pengelola yang dipercaya melakukan kontrak dan menentukan proporsi yang akan diterima masing-masing pihak dari keuntungan yang dihasilkan dan kerugian yang terjadi akan ditanggung bersama (pemilik modal menanggung kerugian finansial, sementara pengelola kehilangan tenaga, waktu dan kesempatan untuk memperoleh keuntungan). Keuntungan yang akan diterima masing-masing pihak ditentukan di awal kontrak dalam bentuk proporsi atau rasio untuk masing-masing pihak, tidak dalam bentuk Angka atau nominal pasti. Keberadaan proporsi inilah kemudian yang diyakini dapat mendeteksi kegagalan dalam aktivitas keuangan yang dijalankan konsumen sebagai pengelola dana ataupun institusi keuangan sebagai pengelola dana investor.

Angka nominal tinggi yang diserahkan pengelola kepada pemilik dana sebagai bagian keuntungan menunjukkan bahwa usaha atau pengelolaan dana yang dilakukan pengelola berjalan dengan baik. Sementara Angka atau nominal yang mengalami penurunan dapat menjadi indikasi bahwa pengelolaan dan yang dilakukan tidak berjalan dengan baik. Berdasarkan indikator tersebut, pemilik dana dapat melakukan penyelidikan lebih lanjut terkait dana yang ia serahkan. Penyelidikan yang dilakukan bisa terkait kinerja pengelola dana, masalah ekonomi yang muncul di lapangan atau persoalan lain yang barangkali dapat mempengaruhi pengelolaan dana. Jika penurunan yang terjadi disebabkan oleh kondisi ekonomi yang memburuk, maka pengelola dapat mengambil langkah-langkah yang tepat untuk mengatasi hal tersebut.

PLS sebagai deteksi dini krisis keuangan dapat dipertimbangkan untuk menjaga stabilitas sistem keuangan nasional. Penggunaan sistem ini tidak hanya tepat pada dunia perbankan, namun dapat diterapkan pada semua jenis lembaga keuangan. Begitu juga, sistem ini tidak hanya khusus dan tepat untuk sistem keuangan Islam. Sistem ini juga dapat diadopsi oleh institusi keuangan konvensional. Tidak perlu menjadi institusi berlabel Islam untuk dapat menggunakan sistem ini jika yang diinginkan adalah stabilitas keuangan secara menyeluruh. 


\section{KESIMPULAN}

Stabilitas keuangan merupakan titik awal pertumbuhan ekonomi dan kesejahteraan masyarakat di setiap negara. Oleh karena itu, setiap negara di dunia selalu berusaha menjaga stabilitas keuangan mereka agar pertumbuhan ekonomi tetap terjaga dan kesejahteraan masyarakat tetap terjamin.

Krisis keuangan merupakan momok bagi setiak sistem keuangan. Kehadiran krisis dapat mengguncang stabilitas sistem keuangan sebuah negara dan dunia. Krisis tersebut bisa terjadi karena utang yang tidak terkendali, regulasi dan pengawasan yang tidak memadai pada sistem keuangan yang bebas ataupun karena mengakarnya spekulasi dalam berbagai aktivitas keuangan.

Krisis keuangan tidak hanya menyinggahi sistem keuangan konvensional yang sudah hadir ratusan tahun di dunia ini. Sistem keuangan Islam yang dianggap baru ada tiga puluh tahun belakangan ini juga tidak luput dari momok yang bernama krisis. Namun, berbeda dengan sistem keuangan konvensional yang sering bahkan mungkin selalu cedera karena ulah krisis, sistem keuangan Islam sepertinya mengalami nasib yang berbeda. Pada krisis keuangan global yang beberapa kali terjadi belakangan ini, sistem keuangan Islam memperlihatkan daya tahan yang berbeda. Di saat hampir keseluruhan sistem keuangan konvensional lumpuh karena krisis, sistem keuangan Islam berhasil bertahan dengan performa yang tetap dan bahkan meningkat.

Imunitas sistem keuangan Islam ini disinyalir sebagai manfaat dari aplikasi prinsipprinsip syariah yang membedakan sistem ini dengan sistem keuangan konvensional. Salah satu prinsip tersebut adalah penggunaan sistem PLS dalam aktivitas keuangan.

Sistem PLS yang menggunakan proporsi sebagai penentu keuntungan antara pemilik modal dengan pengelola modal dapat kiranya mengidentifikasi baik atau tidaknya pengelolaan dana yang dilakukan. Perubahan nominal dari proporsi yang sama yang diterima pemilik modal dapat dijadikan sebagai indikator berhasil atau tidaknya pengelolaan dana yang diserahkan kepada pengelola. Berdasarkan kesimpulan tersebut di atas, maka tulisan ini coba merekomendasikan pengadopsian sistem PLS di seluruh institusi keuangan sebagai pendeteksi awal krisis keuangan.

\section{E. DAFTAR PUSTAKA}

Ahmed, Adel. 2010. "Global Financial Crisis: an Islamic Finance Perspective". International Journal of Islamic and Middle Eastern Finance and Manajemen. Vol. III No.4

Ahmed, H. 2009. "Financial Crisis: Lesson for Islamic Finance", ISRA International Journal of Islamic Finance. Vol.1 No.1

Askari, h., Iqbal, Z., Krichene, N., Mirakhor, A. 2010. The Stability of Islamic Finance: Creating a Resilient Financial Environment for a Secure Future. Singapura: John \& Wiley Sons

BI."What is Financial Stability". www.bi.go.id.

Desiana, Rina. Nonie Afrianty. 2017. "Landasan Etika dalam Ekonomi Islam". Al-Intaj: Jurnal Ekonomi dan Perbankan Islam. Vol.III. No. 1

Dian Mensari, Rizki dan Dzikra, Ahmad. 2017. "Islam dan lembaga keuangan Syariah", AlIntaj; Jurnal Ekonomi dan Perbankan Syariah. Vol.III. No. 1

Dogarawa, A. B. 2012. "Global Financial Crisis and the Search fo New Financial Architecture: 
Can Islamic Finance Provide Alternative?". Journal of Islamic Economics, Banking and Finance. Vol. VIII No.4

Dusuki, A. W. 2011. "The Framework of Maqasid Syariah and Its Implication for Islamic Finance". ISRA Research Paper.

Elasrag, Husein. 2010. Global Financial Crisis and Islamic Finance. Germany:University Library of Munich

Ghassan, B. H. 2013. "Financial Stability of Islamic and Conventional Banks in Saudi Arabia: a Time Series Analysis". DSS Empirical Economics and Econometrics Working Papers Series

Hanafi, S. M. 2006. "Time Value of Money dan Implikasi Ekonomi dalam Ekonomi Islam". EKBISI: Jurnal Ekonomi dan Bisnis Islam. Vol.I No.1

Iqbal, Z., Mirakhor, A. 2011. An Introduction to Islamic Finance: Theory and Practice. Singapura: John Wiley and Sons

Khan, Bilal. Mohammed, Emir A. 2009. "The Value of Islamic Banking in the Current Financial Crisis", Review of banking and Financial Law. Vol. XXIX No. 2

Kettel, B. 2008. Introduction to Islamic Banking and Finance. Northampton: Printhaus

Lestari, Diena. "Manajemen Krisis: FKSSK Perkuat Sistem Deteksi Dini Krisis" Www.finansial.bisnis.com.

Moisseron, J. Y. Teulon, F. 2014. "Are Moral Islamic Economics an Answer to the Global Financial Crisis?". IPAG Business School Working Paper

Moorhouse.A. 2004. An Introduction to Financial Soundness Indicators. London: Monetary and Financial Statistics Bank Of England

Siddiqi. 2008. "The Current Financial Crisis and Islamic Economic". IIUM Journal of Economics and Management, Vol. XVI No.2

Sudrajat, S. d. 2001. Dasar-Dasar Penelitian Ilmiah. Bandung: Pustaka Setia

Wirartha. 2006. Metodologi Penelitian Sosial Ekonomi. Yogyakarta: Andi. 